\title{
Gross signs and histopathology of Ostrea puelchana infected by a Bonamia exitiosa-like parasite (Haplosporidia)
}

\author{
Marina A. Kroeck*
}

Laboratorio de Parasitología e Histopatología de Moluscos Bivalvos LABPAT-IBMP (SENASA LA 0116), Instituto de Biología Marina y Pesquera 'Alte. Storni', (8520), San Antonio Oeste, Rio Negro, Argentina

\begin{abstract}
Haplosporidian microcells belonging to the genus Bonamia parasitise various species of oysters around the world. In Argentina, Bonamia sp. was the causative agent of mass mortality among Ostrea puelchana cultured in San Antonio Bay (San Matías Gulf), and it was detected in natural beds inside San Matías Gulf. In order to describe the gross and histopathological signs caused by Bonamia sp. in O. puelchana, cultured and wild oysters were sampled and analysed by traditional techniques including heart imprints and histology. Cells of Bonamia sp. were observed in connective tissue, free or within haemocytes, in gills and around the digestive gland, stomach, intestine and gonad. Gross signs, histopathological alterations in O. puelchana, and Bonamia sp. cytological morphology resemble those reported for B. exitiosa. However, I propose to treat the Argentinean species as $B$. exitiosa-like until more molecular and ultrastructural studies are conducted to determine the correct taxonomy.
\end{abstract}

KEY WORDS: Bonamia exitiosa-like - Ostrea puelchana · Histopathology · San Matías Gulf · Patagonia $\cdot$ Argentina

Resale or republication not permitted without written consent of the publisher

\section{INTRODUCTION}

Haplosporidian microcells belonging to the genus Bonamia parasitise different species of oysters globally. There are 4 species currently acknowledged that have caused epizootic diseases and mortalities around the world: $B$. ostreae, which infects Ostrea edulis in Europe, Morocco, USA and Canada (Bower 2007); B. exitiosa, which parasitises $O$. chilensis in New Zealand (Hine et al. 2001) and probably O. angasi in Australia (Corbeil et al. 2006); B. roughleyi, which parasitises Saccostrea glomerata in south-east Australia (Cochennec-Laureau et al. 2003); and B. perspora, which infects Ostrea stentina (= Ostreola equestris) in North Carolina (USA; Bishop et al. 2006, Carnegie et al. 2006). Other Bonamia-like microcells have also been described parasitising Crassostrea ariakensis in North Carolina (Burreson et al. 2004) and O. chilensis in
Chile (Kern 1993, Campalans et al. 2000, Lohrmann et al. 2009). In 1996, mass mortality of cultured O. puelchana was reported in San Antonio Bay, Argentina, and Bonamia sp. was identified as a possible aetiological agent (Kroeck \& Montes 2005). This was the first record of a haplosporidian microcell belonging to the genus Bonamia for O. puelchana along its geographical distribution (Fig. 1a). An oyster culture area was identified as the focus of bonamiosis, from which the pathogen spread through the natural oyster beds (Fig. 1c), located at the SW and NE of the San Matías Gulf (Kroeck et al. 2008).

To describe the gross and histopathological signs caused by Bonamia sp. in Ostrea puelchana, cultured and wild oysters were sampled and analysed by traditional techniques including heart imprints and histology. Moreover, to compare to other Bonamia spp., a cytological description of Bonamia sp. was made. 


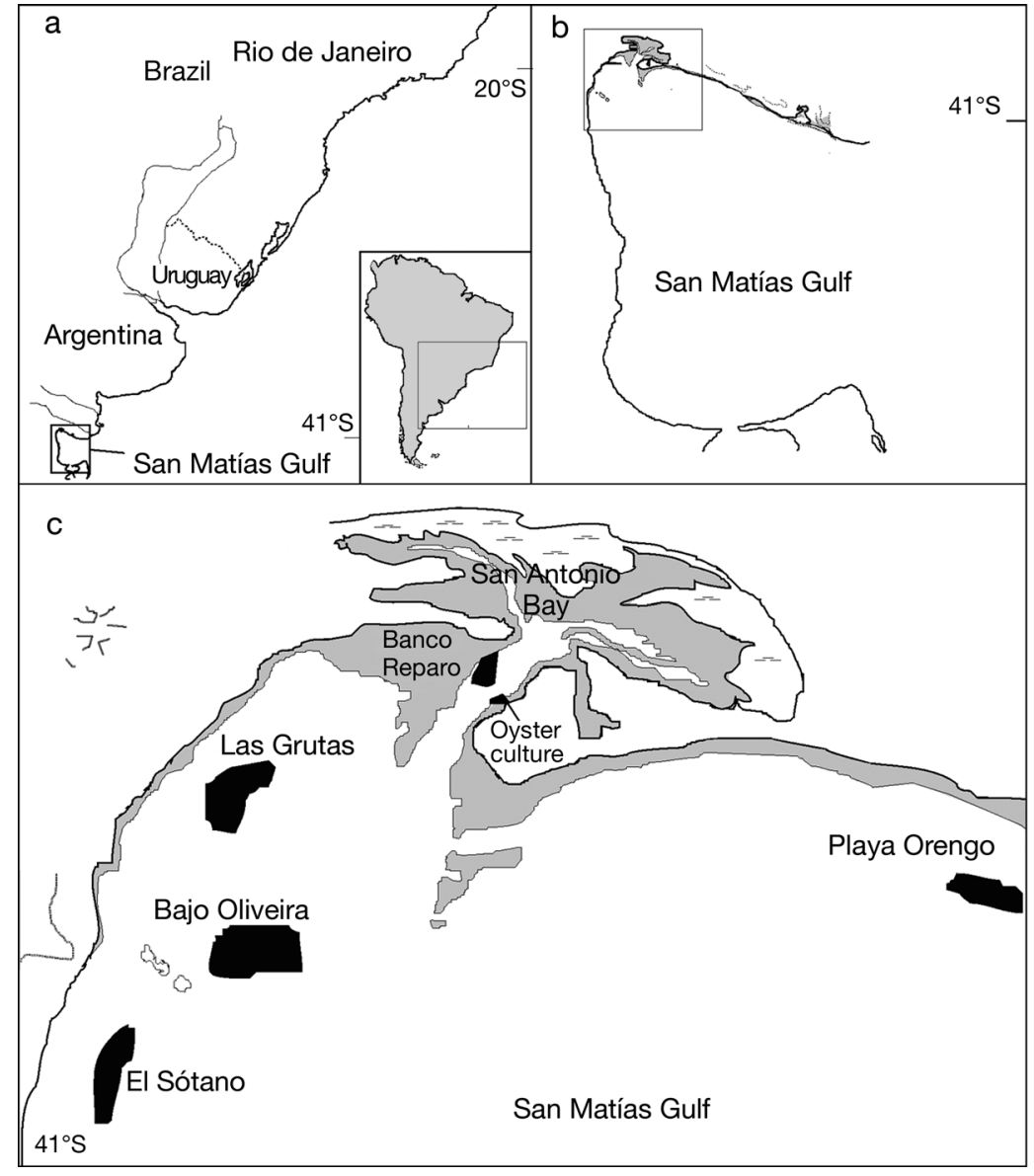

Fig. 1. Study area, oyster culture and sampling sites. (a) Geographical distribution of Ostrea puelchana. (b) Location of San Antonio Bay. (c) Natural beds of O. puelchana and the oyster culture site
Oysters were measured, weighed and opened at the hinge. They were examined for digestive gland colour, apparent condition (fat, medium or watery) and gross abnormalities such as watery cysts, abscesses, tumours and gill lesions. Shell and flesh were separated and weighed, the heart was removed and imprints were made and stained with a 'Tinción 15' Kit (Biopur $\left.{ }^{\circledR} L B\right)$. Soft tissues were fixed in Davidson's solution, embedded in paraffin, cut in $6 \mu \mathrm{m}$ thick sections and stained with Harris ${ }^{\prime}$ haematoxylin-eosin. Heart imprints and histological sections were examined under light microscopy for Bonamia sp. cell morphology and histological lesions and/ or reaction of the host.

To determine the relationship between histology and gross signs, 300 oysters were collected from BR between May 1997 and November 2001. A chisquared test $\left(\chi^{2}\right.$; Sokal \& Rolf 1981) was used to determine the relationship between histological and gross signs in the presence of Bonamia sp. The measurements of cell size were calculated as the means $( \pm \mathrm{SD})$ of the longest dimension and the dimension at right angles to it, divided by 2 .

\section{RESULTS}

\section{MATERIALS AND METHODS}

Between September 1996 and October 2001, samples of 30 oysters were collected semi-annually, in spring and in late summer to early autumn, on each of the 5 natural beds: Banco Reparo (BR), Las Grutas (LG), Bajo Oliveira (BO), El Sótano (ES) and Playa Orengo (PO). Furthermore, samples of 30 oysters (September 1996) and 60 oysters (October 1997) were collected from oyster culture within San Antonio Bay (Fig. 1c).
In total, 1288 Ostrea puelchana were collected and analysed; of these, 1198 came from 5 natural beds, and the 90 remaining were collected from the commercial cultivation. Parasite prevalence of wild and cultured oysters was $21 \%$ and $63.3 \%$, respectively.

\section{Gross signs associated with Bonamia sp. infection}

Gross abnormalities such as watery cysts, abscesses and watery cysts and tumours were not observed.

Table 1. Ostrea puelchana. Prevalence (\%) of Bonamia sp. in relation to gross signs and haemocytic infiltration. (Total no. oysters $=300 ;$ total no. infected $=93 ;$ thus, total prevalence $=31 \%$ )

\begin{tabular}{|c|c|c|c|c|c|c|}
\hline & \multicolumn{5}{|c|}{ - Gross signs } & \multirow{3}{*}{$\begin{array}{l}\text { Haemocytic } \\
\text { infiltrations }\end{array}$} \\
\hline & \multicolumn{2}{|c|}{ Digestive gland colour } & \multicolumn{2}{|c|}{ Apparent condition } & \multirow{2}{*}{$\begin{array}{c}\text { Gill } \\
\text { lesions }\end{array}$} & \\
\hline & Normal & Pale & Fat/medium & Watery & & \\
\hline No. oysters (\%) & $262(87.3)$ & $38(12.7)$ & $242(80.7)$ & $58(19.3)$ & $70(23.3)$ & $230(76.7)$ \\
\hline Prevalence & 26.3 & 4.7 & 24.3 & 6.7 & 9.7 & 21.3 \\
\hline
\end{tabular}




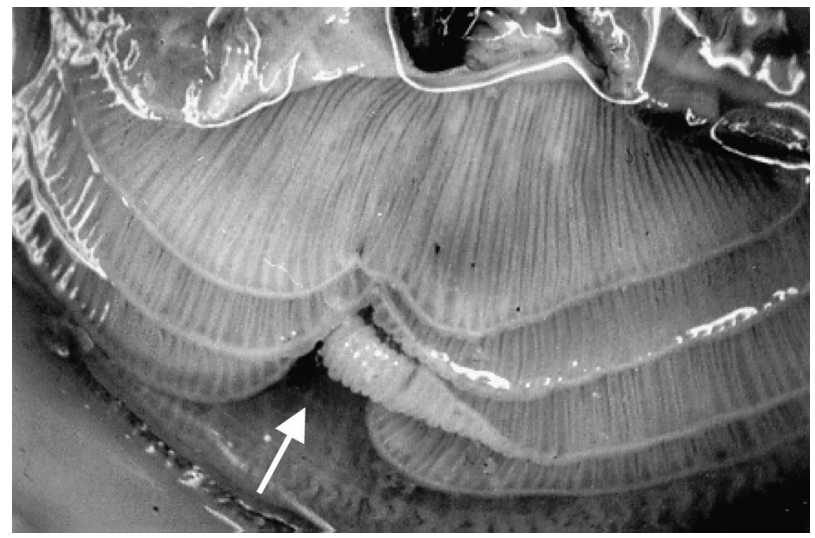

Fig. 2. Ostrea puelchana. Gill lesions (arrow)

From the sub-sample of 300 oysters collected at BR, 93 $(31.0 \%)$ were infected by Bonamia sp. Abnormal clear or pale colouration of the digestive gland was observed in $38(12.7 \%)$ oysters, and $4.7 \%$ of them were heavily parasitised (Table 1). This pale colouration was independent $(0.69$; p > 0.05) of Bonamia sp. presence and in moderate/low infections was not observed. Oysters with watery condition $(19.3 \%)$ were spawning or spent, and a low percentage of them (6.7\%) were parasitised (Table 1). The presence of infection was independent $(0.41 ; \mathrm{p}>0.05)$ of the condition (fat, medium or watery) of Ostrea puelchana. Some oysters (70/300) presented gill lesions (Fig. 2), and $9.7 \%$ of them were parasitised (Table 1). The presence of gill lesions was not independent of the presence of the parasite (5.7; $\mathrm{p}<0.05)$; however, the degree of association was low $(\mathrm{C}=0.138)$.

\section{Histopathological alterations associated with Bonamia sp. infection}

Histological examination revealed the presence of marked haemocyte infiltration in connective tissue of the mantle, gills and digestive gland, with parasitised and non-parasitised haemocytes (Figs. $3 \& 4$ ). From the sub-sample of 300 oysters collected at BR, 156 showed haemocyte infiltration, of which $89(29.7 \%)$ were parasitised (Table 1). The presence of haemocyte infiltration was not independent of the presence of the parasite $(103.12 ; \mathrm{p}<0.05)$, with a relatively high degree of association $(\mathrm{C}=0.548)$

During spawning periods (November to December and February to March), haemocytes accumulated around and inside the gonads (Fig. 3a). Entry of Bonamia in haemocytes into the gonad occurs particularly during reabsorption of ovacytes in April to May. Infected haemocytes and free Bonamia between ovacytes could be observed (Fig. 4d).
Haemocyte infiltration was most common in the vesicular connective tissue (VCT) around the digestive gland, particularly around stomach, intestine and digestive diverticulae (Fig. 3b,d). Infiltration was accompanied by disassociation of VCT containing cell debris, broken haemocytes with picnotic nuclei and parasitised granular haemocytes (Fig. 4a-c).

Gills infected with Bonamia sp. showed haemocyte infiltration of the connective tissue and, less frequently, hypertrophy of the filaments (Fig. 3c). In heavily infected oysters, haemocytes spread from the suprabranchial area into the gills, sometimes causing rupture of the epithelium and release of parasitised and non-parasitised haemocytes (Fig. 3e).

\section{Cytological description of Bonamia sp.}

Parasitised haemocytes had an eccentric nucleus, and usually 1 or 3 , but up to 7 or 8 , parasites were located inside a parasitophorous vacuole (PV) in the cytoplasm (Figs. 4a,b \& 5).

Bonamia sp. cells are spherical or ovoid and range in size from 3.7 to $4.2 \mu \mathrm{m}$. They have a basophilic, and sometimes eosinophilic cytoplasm and a central circular nucleus.

Four stages of Bonamia sp. were observed:

(1) Uninucleate form. This cell form was observed both in light infections and in highly parasitised oysters. It was distinguished by its small size $(2.7 \pm 0.3$ to $3.1 \pm 0.3 \mu \mathrm{m}$, mean $\pm \mathrm{SD})$, irregular and spherical shape, with a central nucleus (Fig. 4c,d). Basophilic uninucleate cells occurred from September to November and were rarely observed in late summer to early fall samples. Otherwise, eosinophilic uninucleate cells were observed in March and April, mainly during reabsorption of ovacytes of wild oysters. However, they were also observed during the months in which high mortality of farmed oysters occurred in September 1996 and October 1997. In semi-thin sections, they were seen as dense and clear forms (Fig. 5a).

(2) Bi-nucleate form. This form was distinguished by its 2 nuclei, slightly larger size $(3.3 \pm 0.2$ to $4.0 \pm 0.3 \mu \mathrm{m}$, mean $\pm \mathrm{SD}$ ), ovoid but sometimes spherical shape and slightly more eosinophilic cytoplasm (Fig. 4b). Occurrence of this stage was only observed in April and August.

(3) Plasmodial-like form. This stage was observed only in April and August samples. It was distinguished by its irregular shape, eosinophilic cytoplasm with 3 , rarely 4 , nuclei and was slightly larger (4 to $5 \mu \mathrm{m}$ ) than bi-nucleate form (Figs. 4c \& 5).

(4) Vacuolate-like form. This form was distinguished by a poorly delineated nucleus, with cytoplasm around a central vacuole. The nucleus was eccentric, giving 


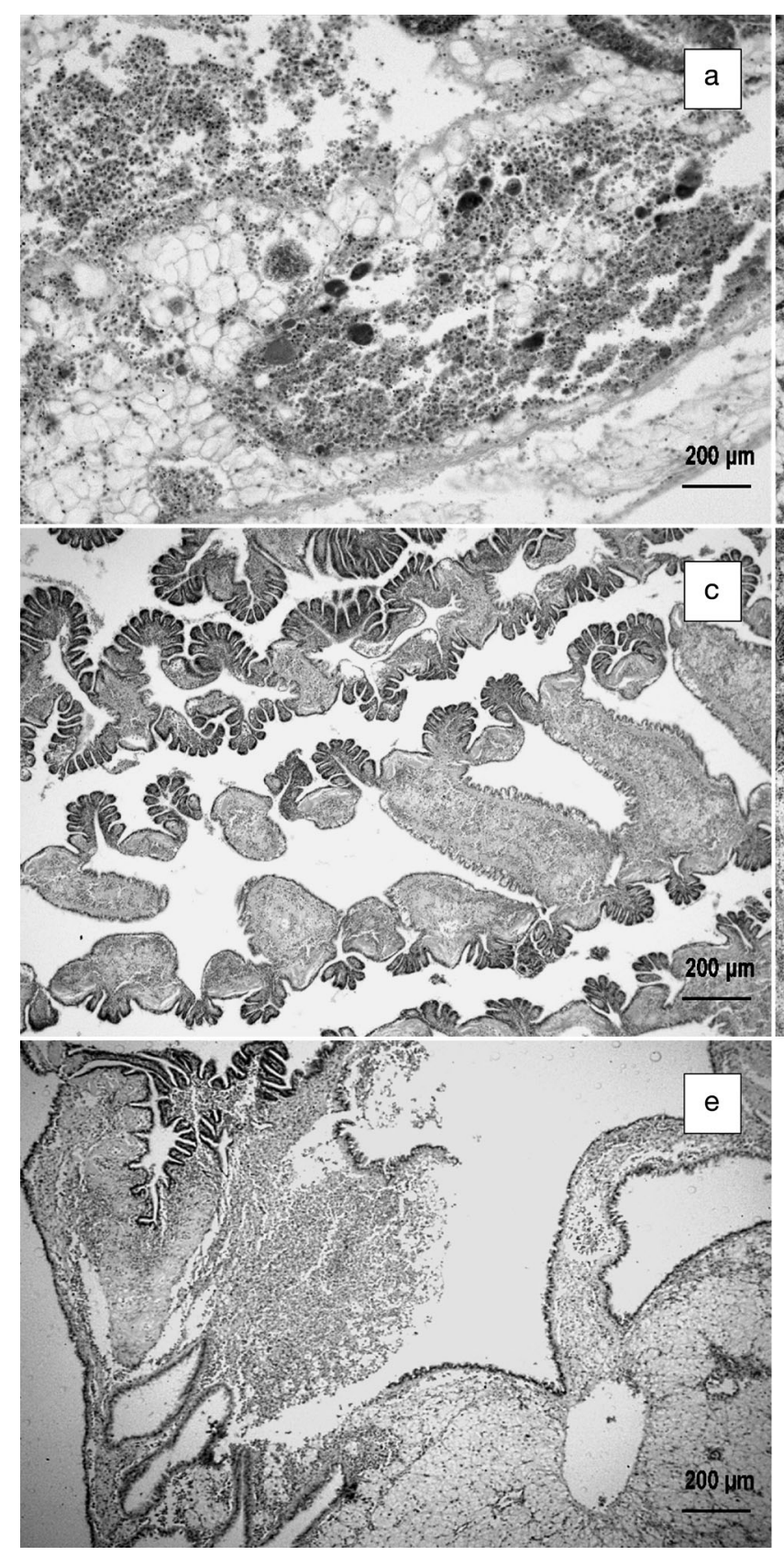

the cell section the appearance of a signet ring (Fig. 5a,d). This cell form was only observed in April, in the semi-thin sections.

\section{DISCUSSION}

Gross signs and histopathological alterations associated with Bonamia sp. infection

In all Ostrea puelchana, gross signs such as watery cysts, abscesses or tumours were not observed. Al-

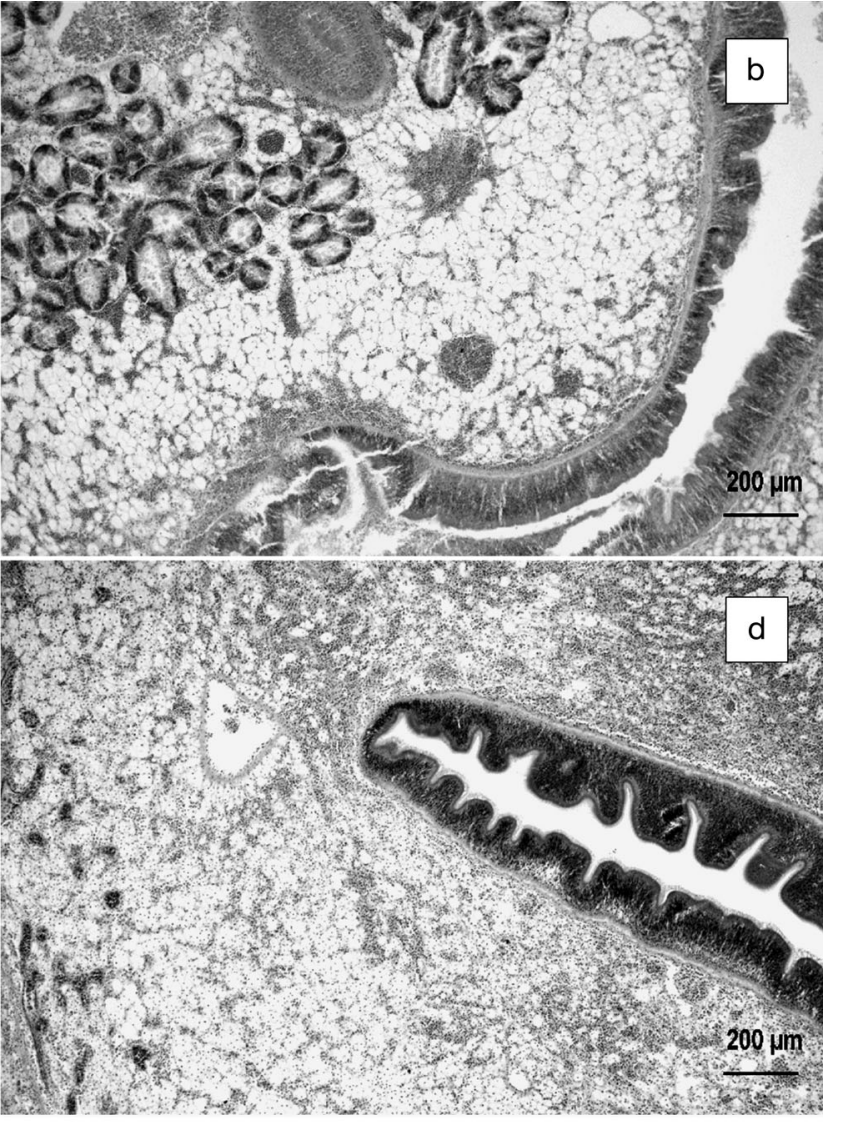

Fig. 3. Ostrea puelchana Light microscopy of histopathological alterations in oysters infected by a Bonamia exitiosa-like pathogen. Haematoxylin-eosin-stained sections. (a) Haemocytes accumulated inside and around the gonads during ovacytes reabsorption. (b) Focal haemocyte infiltration in vesicular connective tissue (VCT), around digestive gland and below the basement membrane of the gut. (c) Infected gills showed haemocyte infiltration and hypertrophy of the filaments. (d) Haemocyte infiltration in VCT and below the basement membrane of the gut. (e) Release of parasitised and non-parasitised haemocytes due to rupture of the gill epithelium

though some parasitised oysters had pale colouration of the digestive gland and a watery condition were observed, these external signs were not associated with Bonamia sp. presence. This has also been reported for $O$. chilensis in New Zealand parasitised by Bonamia exitiosa (Dinamani et al. 1987, Hine \& Jones 1994) and for O. edulis in Galicia (Spain) infected by $B$. ostreae (Montes 1992).

Gill lesions were observed in $23.3 \%$ of the analysed oysters, but only $9.7 \%$ of them were parasitised. Dinamani et al. (1987) found a similar percentage (10\%) for infected oysters with frayed and badly eroded gills. A 


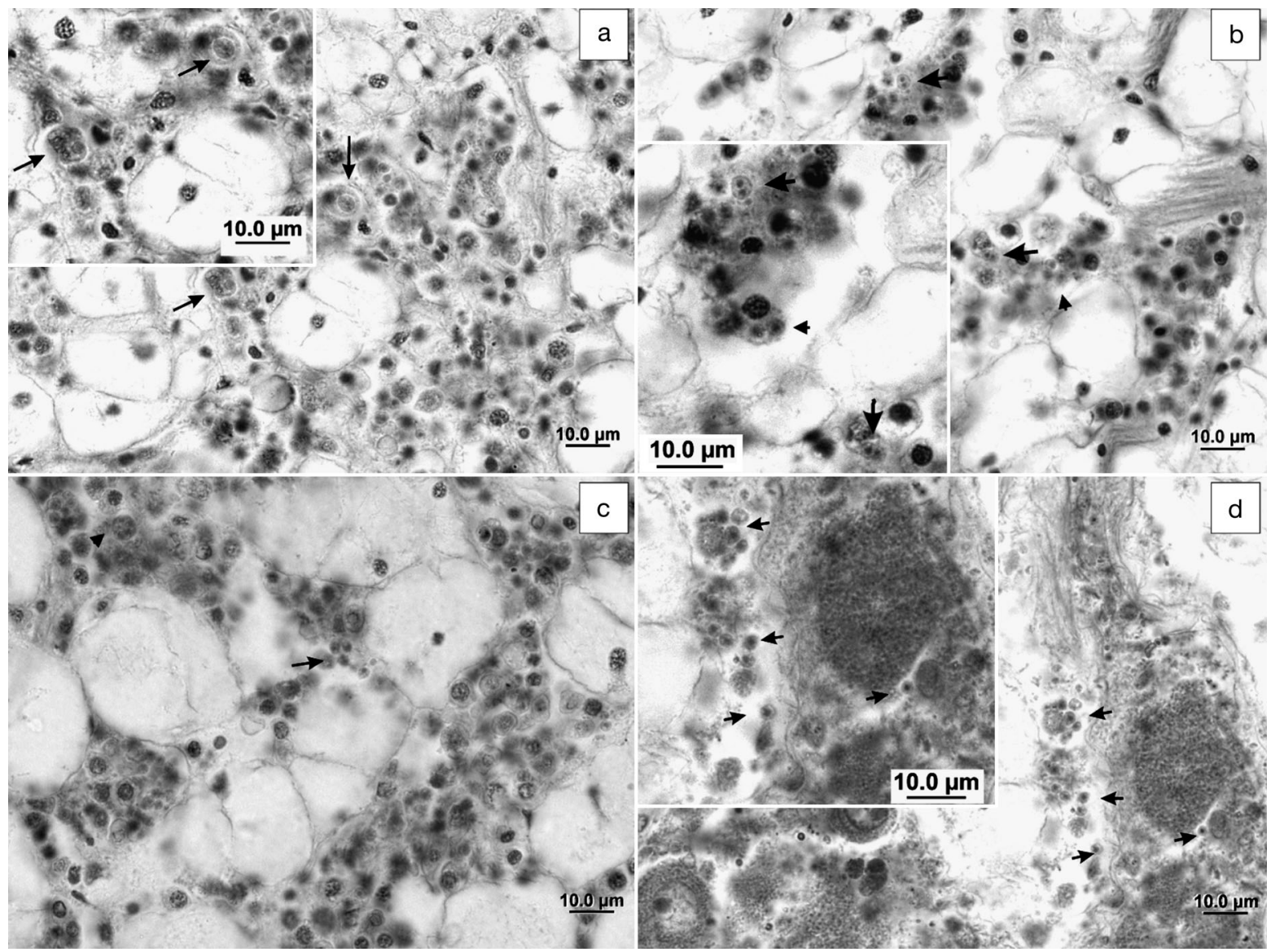

Fig. 4. Ostrea puelchana. Light microscopy of the Bonamia exitiosa-like pathogen in haematoxylin-eosin-stained sections. (a) Haemocytes with eccentric nucleus infected by $1 \mathrm{~B}$. exitiosa-like cell inside a parasitophorous vacuole (PV; arrows). Insert: Uninucleate cell with an indented or concave region of the parasite surface at higher magnification. (b) Uninuclate (small arrow) and free binucleate (large arrow) cell forms. Insert: Two uninuclate (small arrow) cell forms inside the same PV and free binucleate (large arrow) cell forms at higher magnification. (c) Free uninucleate (arrow) and plasmodial-like (arrowhead) forms.

(d) Free uninucleate cell forms (arrows) between ovacytes. Insert: The same cell forms at higher magnification

yellowish band at the ending of gill lesions was described for Ostrea edulis (Tigé et al. 1980); however, this band was not observed in O. puelchana. Moreover, several authors (Tigé et al. 1980, Grizel et al. 1988, Mc Ardle et al. 1991, Montes 1992) reported gill lesions as characteristic of bonamiosis caused by Bonamia ostreae in O. edulis. However, although in $O$. puelchana gill lesions were the only external signs significantly associated with the presence of the parasite, the degree of association was low. Therefore, frayed or eroded gills cannot be considered as pathognomonic for infection by Bonamia sp. in O. puelchana. These symptoms may also have been due to other causes, such as congenital, environmental or mechanical factors.

Prevalence of Bonamia sp. and the percentages of haemocytic infiltrations are dependent events with a relatively high degree of association. The differences between parasite prevalence and percentages of infiltration values are probably due to some stress problems that cause these tissue reactions (Hine et al. 2002), or due to a 'latent period' as in Ostrea edulis parasitised by B. ostreae (Culloty et al. 2003). These tissue reactions could also be due to other infections such as viral infections (Da Silva et al. 2005).

The most important microscopic signs of Bonamia sp. infection in Ostrea puelchana are (1) dense cellular accumulations due to haemocytic infiltration in all connective tissue (systemic infiltration), (2) dissociated appearance of connective tissue containing lysed haemocytes with picnotic nuclei and cells debris (Kroeck \& Montes 2005; Figs. 2 to 4), and (3) intracellular localisation of Bonamia sp. (1-7 parasites per haemocyte) or parasites lying free between cells in connective tissue (Figs. 4 \& 5).

The same histopathological alterations have been reported for Ostrea edulis, $O$. angasi and $O$. chilensis 

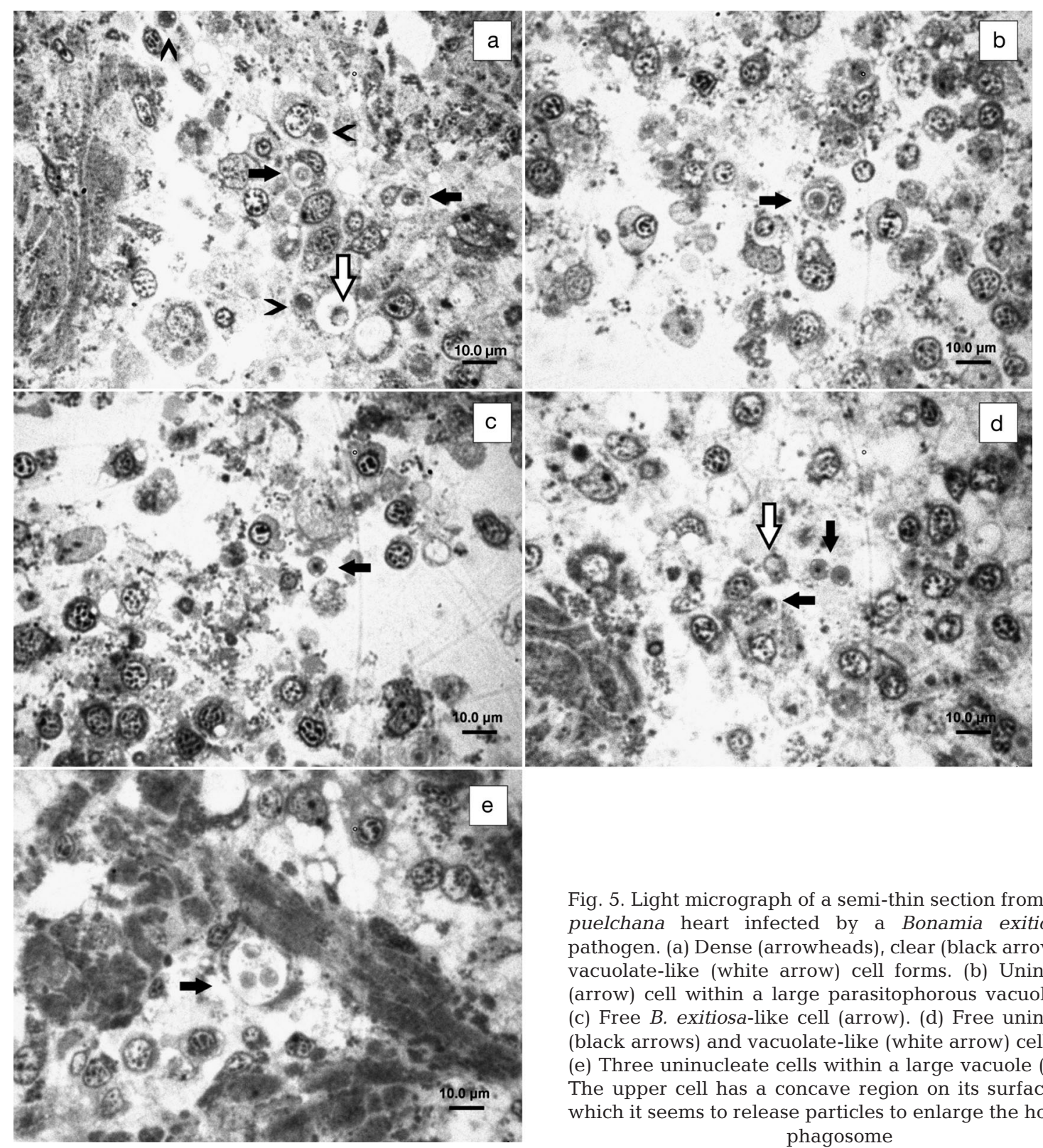

Fig. 5. Light micrograph of a semi-thin section from Ostrea puelchana heart infected by a Bonamia exitiosa-like pathogen. (a) Dense (arrowheads), clear (black arrows) and vacuolate-like (white arrow) cell forms. (b) Uninucleate (arrow) cell within a large parasitophorous vacuole (PV). (c) Free $B$. exitiosa-like cell (arrow). (d) Free uninucleate (black arrows) and vacuolate-like (white arrow) cell forms. (e) Three uninucleate cells within a large vacuole (arrow). The upper cell has a concave region on its surface, from which it seems to release particles to enlarge the host phagosome

parasitised by Bonamia ostreae and B. exitiosa (Dinamani et al. 1987, Grizel et al. 1988, Mc Ardle et al. 1991, Montes 1992, Hine et al. 2001). Similar conditions have been observed in tissue and cells of other Ostrea spp. parasitised by Bonamia spp. (Poder et al. 1982, Balouet et al. 1983, Bucke \& Feist 1985, Elston et al. 1986, Farley et al. 1988, Friedman et al. 1989, Hine 1991a,b, Chagot et al. 1992, Friedman \& Perkins 1994, Hine \& Wesney 1994, Montes et al. 1994).

In previous studies, conducted on samples of farmed oysters collected in September 1996 and October 1997, the occurrence of Bonamia sp. in the gonad was never observed (Kroeck \& Montes 2005). However, further studies (Kroeck et al. 2008), carried out between September 1996 and October 2001 on wild oysters, revealed the presence of this pathogen during spawning peaks, particularly inside gonads during ovacyte reabsorption. Like Ostrea chilensis (Hine, 1991a), O. puelchana spawn in early summer to autumn (November to December and February to March; Morriconi \& Calvo 1979), and in April most of the oysters are spawned with accumulation of parasitised and nonparasitised haemocytes around and inside the gonads. Hine $(1991 \mathrm{a}, \mathrm{b})$ reported that $B$. exitiosa infections display a seasonality closely following $O$. chilensis gametogenesis and reproductive cycle. Parasites proliferate 
when haemocytes migrate into the gonad to resorb unspawned gametes (Dinamani et al. 1987, Hine 1991a,b, Carnegie \& Cochennec-Laureau 2004). The similarity of the gonadal development and gonadal infection patterns in both ostreids could explain the fact that Bonamia cells were not observed within the farmed O. puelchana gonads in September 1996 and October 1997.

\section{Comparison of cytological and developmental stages of Argentinean Bonamia sp. to other known Bonamia spp.}

Different developmental stages have been reported for haplosporidian microcells belonging to the genus Bonamia (Pichot et al. 1980, Dinamani et al. 1987, Hine 1991b, Hine et al. 2001, Cochennec-Laureau et al. 2003, Carnegie et al. 2006, Abollo et al. 2008, Lohrmann et al. 2009). Uninucleate small $(<5 \mu \mathrm{m})$ cells are characteristic of microcell haplosporidians. These cells may be electron dense or electron clear (Pichot et al. 1980, Dinamani et al. 1987, Hine 1991a,b) with eccentric nuclei in $B$. ostreae (Friedman et al. 1989) or central nuclei, as is characteristic of $B$. exitiosa (Hine et al. 2001).

Argentinean Bonamia sp. uninucleate cells resemble $B$. exitiosa in the central circular nucleus and size $(3.1 \pm 0.3 \mu \mathrm{m}$ and $3.1 \pm 0.4 \mu \mathrm{m}$, respectively; Hine 1991a,b, Hine et al. 2001, Abollo et al. 2008). Also, they resemble each other in an indented or concave region of the parasite surface (Fig. 4a; see also Hine 1991b: Figs. 1 \& 6; Hine \& Wesney 1994: Figs. 14 \& 15; Hine et al. 2001: Fig. 13), and particle release appeared to coincide with host phagosome membrane enlargement, forming a PV around the parasite (Figs. 4a \& 5e; see also Hine 1991b: Fig. 8; Hine \& Wesney 1994: Fig. 16). Moreover, Argentinean Bonamia sp. and New Zealand $B$. exitiosa resemble each other in the occurrence and seasonality of basophilic and eosinophilic uninucleate forms, as well as their seasonal prevalence pattern (Hine 1991a, Kroeck et al. 2008).

The occurrence of binucleated cells was reported in Bonamia ostreae in vitro culture assays (Comps 1983). Hine et al. (2001), Abollo et al. (2008), Lohrmann et al. (2009) and Carnegie et al. (2006) also reported the occurrence of binucleated cells for $B$. exitiosa, Chilean Bonamia sp. and B. perspora, respectively. Argentinean Bonamia sp. binucleated cells resemble those of B. perspora in size $(4.0 \pm 0.3 \mu \mathrm{m}$ and $4.0 \pm 0.9 \mu \mathrm{m}$, respectively) and in their spherical but more often ovoid shape (Fig. 4b). Moreover, Bonamia sp. binucleated cells co-occurred with uninucleated cell forms (Fig. 4b), as in B. perspora (Carnegie et al. 2006).
The occurrence of plasmodial cells has been observed regularly in Bonamia exitiosa (Hine 1991b, Hine et al. 2001). B. ostreae plasmodia occur rarely only in moribund or post-morten oysters (Brehélin et al. 1982), similar to B. roughleyi plasmodia (Cochennec-Laureau et al. 2003). The Bonamia sp. plasmodiallike form has been observed only in April and August samples. It resembles $B$. exitiosa in Ostrea edulis (see Abollo et al. 2008: Fig. 1) and B. perspora small plasmodia (see Carnegie et al. 2006: Fig. 1). It was extracellular, and distributed throughout oyster connective tissue as in B. perspora (Carnegie et al. 2006).

The Bonamia sp. vacuolated-like form was only observed in April in the semi-thin sections (Fig. 5a,d) and resembled $B$. exitiosa in having a poorly delineated nucleus with cytoplasm around a large vacuole (perhaps a vacuous mitochondrium; see Hine et al. 2001: Figs. 13 \& 14).

Gross signs and histopathology in Ostrea puelchana, as well as cytology and developmental stages of Bonamia sp. resemble those reported for $B$. exitiosa. The Argentinean species is considered to be $B$. exitiosa-like, until more molecular and ultrastructural studies determine the correct taxonomy.

Acknowledgements. I thank E. Zampatti for generously providing the cultured oysters for this study, A. Medina for his technical assistance in light micrograph of a semi-thin section from O. puelchana heart and R. Carnegie for help during my research. I also thank P. M. Hine for help during my research, suggestions on this manuscript and especially for invaluable professional support. This study was part of my Doctoral Thesis Research Project at the Universidad Nacional del Comahue, S.C. de Bariloche, Río Negro, Argentina (C.R.U.B) and was financially supported by the Secretaria de Investigación (Universidad Nacional del Comahue).

\section{LITERATURE CITED}

Abollo E, Ramilo A, Casas SM, Comesaña P, Cao A, Carballal MJ, Villalba A (2008) First detection of the parasite Bonamia exitiosa (Haplosporidia) infecting flat oyster Ostrea edulis grown in European waters. Aquaculture 274:201-207

> Balouet G, Poder M, Cahour A (1983) Haemocytic parasitosis: morphology and pathology of lesions in French flat oyster, Ostrea edulis L. Aquaculture 34:1-14

Bower SM (2007) Synopsis of infectious diseases and parasites of commercially exploited shellfish: Bonamia ostreae of oysters. Available at: www.pac.dfo-mpo.gc.ca/science/ species-especes/shellfish-coquillages/diseases-maladies/pages/bonostoy-eng.htm

Brehélin M, Bonami JR, Cousserans F, Vivares C (1982) Existence des formes plasmodiales vraies chez Bonamia ostreae, parasite de l'huitre plate Ostrea edulis. C R Acad Sci Serie III Sci Vie 295:45-48

Bucke D, Feist S (1985) Bonamiasis in the flat oyster, Ostrea edulis, with comments on histological techniques. In: Ellis AE (ed) Fish and shellfish pathology. Academic Press, London, p 387-392 
Burreson EM, Stokes NA, Carnegie RB, Bishop MJ (2004) Bonamia sp. (Haplosporidia) found in non-native oysters Crassostrea ariakensis in Bogue Sound, North Carolina. J Aquat Anim Health 16:1-9

Campalans M, Rojas P, González M (2000) Haemocytic parasitosis in the farmed oyster Tiostrea chilensis. Bull Eur Assoc Fish Pathol 20:31-33

Carnegie RB, Cochennec-Laureau N (2004) Microcell parasites of oysters: recent insights and future trends. Aquat Living Resour 17:519-528

Carnegie RB, Burreson EM, Hine PM, Stokes NA, Audemard C, Bishop MJ, Peterson CH (2006) Bonamia perspora n. sp. (Haplosporidia), a parasite of the oyster Ostreola equestris, is the first Bonamia species known to produce spores. J Eukaryot Microbiol 53:232-245

$>$ Chagot D, Boulo V, Hervio D, Mialhe E, Mourton C, Grizel H (1992) Interactions between Bonamia ostreae (Protozoa: Ascetospora) and haemocytes of Ostrea edulis and Crassostrea gigas (Mollusca: Bivalvia): entry mechanisms. Invertebr Pathol 59:241-249

Cochennec-Laureau N, Reece KS, Berthe FCJ, Hine PM (2003) Mikrocytos roughleyi taxonomic affiliation leads to the genus Bonamia (Haplosporidia). Dis Aquat Org 54: 209-217

Comps M (1983) Culture in vitro de Bonamia ostreae, parasite hémocytaire de l'huitre plate Ostrea edulis. C R Acad Sci Serie III Sci Vie 296:931-933

Corbeil S, Arzul I, Robert M, Berthe FCJ, Besnard-Cochennec N, Crane MSJ (2006) Molecular characterisation of an Australian isolate of Bonamia exitiosa. Dis Aquat Org 71:82-85

Culloty SC, Cronin MA, Mulcahy MF (2003) Possible limitations of diagnostic methods recommended for the detection of the protistan, Bonamia ostreae in the European flat oyster, Ostrea edulis. Bull Eur Fish Pathol 23:67-71

Da Silva PM, Fuentes J, Villalba A (2005) Growth, mortality and disease susceptibility of oyster Ostrea edulis families obtained from brood stocks of different geographical origins, through on-growing in the Ría de Arousa (Galicia, NW Spain). PSZN I: Mar Ecol 147:965-977

Dinamani P, Hine PM, Jones JB (1987) Occurrence and characteristics of the haemocyte parasite Bonamia sp. in the New Zealand dredge oyster Tiostrea lutaria. Dis Aquat Org 3:37-44

Elston RA, Farley CA, Kent ML (1986) Occurrence and significance of bonamiasis in European flat oysters Ostrea edulis in North America. Dis Aquat Org 2:49-54

Farley CA, Wolf PH, Elston RA (1988) A long-term study of 'microcell' disease in oysters with a description of a new genus, Mikrocytos (gen. n.), and two new species, $M$. mackini (sp. n.) and M. roughleyi (sp. n.). Fish Bull (Seattle) 86:581-593

Friedman CS, Perkins FO (1994) Range extension of Bonamia ostreae to Maine, USA. J Invertebr Pathol 64:179-181

Friedman CS, Mc Dowell T, Groff JM, Hollibaugh JT, Manzer D, Hedrick RP (1989) Presence of Bonamia ostreae among populations of the European flat oyster, Ostrea edulis Linné, in California, USA. J Shellfish Res 8:133-137

Grizel H, Mialhe E, Chagot D, Boulo V, Bachere E (1988)

Editorial responsibility: Mike Hine,

Fouras, France
Bonamiasis: a model study of disease in marine mollusc. Am Fish Soc Spec Pub 18:1-4

Hine PM (1991a) The annual pattern of infection by Bonamia sp. in New Zealand flat oysters, Tiostrea chilensis. Aquaculture 93:241-251

Hine PM (1991b) Ultrastructural observations on the annual infection pattern of Bonamia sp. in flat oysters Tiostrea chilensis. Dis Aquat Org 11:163-171

Hine PM, Jones JB (1994) Bonamia and other aquatic parasites of importance to New Zealand. NZ J Zool 21:49-56

Hine PM, Wesney B (1994) Interaction of phagocytosed Bonamia sp. (Haplosporidia) with haemocytes of oysters (Tiostrea chilensis). Dis Aquat Org 20:219-229

> Hine PM, Cochennec N, Berthe FCJ (2001) Bonamia exitiosus n. sp. (Haplosporidia) infecting flat oyster Ostrea chilensis in New Zealand. Dis Aquat Org 47:63-72

Hine PM, Diggles BK, Parsons MJD, Pringle A, Bull B (2002) The effects of stressors on the dynamics of Bonamia exitiosus Hine, Cochennec-Laureau \& Berthe, infections in flat oysters Ostrea chilensis (Philippi). J Fish Dis 25:545-554

Kern FG (1993) Shellfish health inspections of Chilean and Australian oysters. J Shellfish Res 12:366 (Abstract)

> Kroeck MA, Montes J (2005) Occurrence of the haemocyte parasite, Bonamia sp., in flat oysters, Ostrea puelchana d'Orbigny, farmed in San Antonio Bay (Argentina). Dis Aquat Org 63:231-235

> Kroeck MA, Semenas L, Morsan EM (2008) Epidemiological study of Bonamia sp. in the native flat oyster, Ostrea puelchana from San Matías Gulf (NW Patagonia, Argentina). Aquaculture 276:5-13

> Lohrmann KB, Hine PM, Campalans M (2009) Ultrastructure of Bonamia sp. in Ostrea chilensis in Chile. Dis Aquat Org 85:199-208

> McArdle JF, McKiernan F, Foley H, Jones DH (1991) The current status of Bonamia disease in Ireland. Aquaculture 93: $273-278$

Montes J (1992) Estudio de la Bonamiasis de la ostra plana (Ostrea edulis L.) en Galicia. Epidemiología y ciclo celular. $\mathrm{PhD}$ thesis. Universidad de Santiago de Compostela

Montes J, Anadón R, Azevedo C (1994) A possible life cycle for Bonamia ostreae on the basis of electron microscopy studies. J Invertebr Pathol 63:1-6

Morriconi ER, Calvo J (1979) Ciclo reproductivo y alternancia de sexos en Ostrea puelchana. Physis 95:1-17

Pichot Y, Comps M, Tigé G, Grizel H, Rabouin MA (1980) Recherches sur Bonamia ostreae gen. n., sp. n., parasite nouveau de l'huitre plate Ostrea edulis. Rev Trav Inst Pech Marit 43:131-140

Poder M, Cahour A, Balouet G (1982) Hemocytic parasitosis in European oyster Ostrea edulis L: pathology and contamination. Proc XVth Annu Meeting Soc Invertebr Pathol, Brighton, p 254-257

Sokal RR, Rolf FJ (1981) Biometría: principios y métodos estadísticos en la investigación biológica. H. Blume (eds), San Francisco, CA

Tigé G, Grizel H, Comps M (1980) Données sur le nouveau parasite de l'huître plate. Situation epidemiologique. Cons Int Explor Mer CM 1980/F:39, Copenhagen

Submitted: July 30, 2009; Accepted: November 25, 2009

Proofs received from author(s): March 8, 2010 